\section{B A Institute of \\ YK Business Administration \\ 六下 \\ Karachi \\ Leadership and Ideas for Tomorrow}

Business Review

Volume 9 Issue 2 July-December 2014

$7-1-2014$

\title{
Book Review of: Nazlkramullah. Ganga Jumuni: Silver and Gold, A Forgotten Culture. Bengal Publications, 2013
}

Nadya Chishty-Mujahid

Institute of Business Administration,Karachi.

Follow this and additional works at: https://ir.iba.edu.pk/businessreview

Part of the Social and Behavioral Sciences Commons

\section{c) (7)}

This work is licensed under a Creative Commons Attribution 4.0 International License.

\section{Recommended Citation}

Chishty-Mujahid, N. (2014). Book Review of: Nazlkramullah. Ganga Jumuni: Silver and Gold, A Forgotten Culture. Bengal Publications, 2013. Business Review, 9(2), 198-199. Retrieved from https://doi.org/ 10.54784/1990-6587.1280

This article is brought to you by iRepository for open access under the Creative Commons Attribution 4.0 License and is available at https://ir.iba.edu.pk/businessreview/vol9/iss2/14. For more information, please contact irepository@iba.edu.pk. 


\title{
NEWS AND VIEWS
}

\section{Nazlkramullah. Ganga Jumuni:}

\author{
Silver and Gold, A Forgotten Culture. \\ Bengal Publications, 2013.
}

Respected artist NazIkramullah comes from a noted pedigree when it comes to writing in general, and writing by women in particular. Her mother, the late Begum Shaista Ikramullah was one of the sub-continent's most revered female political figures. The first South Asian woman to receive a foreign doctoral degree, she served as foreign ambassador to several countries, including Morocco. Mrs. Ikramullah authored two informative books; her autobiography, From Purdah to Parliament, and Behind the Veil. One of her other daughters, Princess Sarvath of Jordan, wrote the foreword to an edition of Daulat Hidayatullah Haroon's biography of her late father, Abdullah Haroon. At the recent Karachi Literature Festival, while launching her book Ganga Jamuni, Ms. Ikramullah noted that being primarily an artist, she never considered herself capable of writing a book until urged to do so by the eminent Bangladeshi jurist, Dr. Kamal Hossain. Her debut literary endeavour examines the confluence of two divergent streams of culture in South Asia, the Hindu and the Muslim-hence the book's title, which indicates a merging of the golden with the silver.

Ms. Ikramullah introduces her text by claiming that syncretic cultures are often enriched by the manner in which their influences shape and formulate each other. This merging influences a variety of aspects including, but not limited to, literature, art, music, poetry and history, not to mention sundry social customs. She draws our attention to the point that, in 2010, the Jang group of Pakistan, and The Times group of India launched a peace initiative titled Amanki Asha, that brings musical events and book readings concerning both Hindu and Muslim cultures to the forefront. In her first chapter, the author credits the Mughal emperors (many of whom had wives chosen from amongst the Hindus) as well as the Sufi tradition with this important and historical promotion of syncretic thought and action. Referring to Aurangzeb Alamgir several times over the course of the book, the author notes that although he is often portrayed as a strict, almost fundamentalist Muslim, he was nevertheless deeply influenced by Hindu customs; even to the extent of having his hands dyed with henna at his wedding! Her second chapter examines both Sufi doctrine as well as Hindu Bhakti thought, and displays a sound knowledge of the ways in which Muslims and Hindus alike regarded the interesting and complex god, Krishna. Her next chapter begins by dwelling on the marked influence of the Bengali Bauls on sub-continental music. Moving on to the realm of architecture, she notes how (regardless of the extensive and beautiful use of Arabic calligraphy in mosques) structures such as Delhi's famous QutubMinar display figures from Hindu mythology. Commenting on literature and language, although she notes that Amir Khusrau used the Purbi (or Awadhi) language in the thirteenth century, Urdu (a mixture of Hindi and Persian) itself did not become commonly utilized for literary texts until the eighteenth century. In spite of the general focus of her book being a socio-historical perspective, Ms. Ikramullah does not fail to mention modern contributors to South Asian culture, such as the talented, Pakistani-born artist, ShaziaSikander. Indeed, the cover of her text displays the well-known Pakistani dancer SheemaKirmaniwearing a bluepeshwaz(full skirt, bodice, and pajamas)striking an elegant dance-pose. Finally, the author moves towards the realm of what she regards as cultural fusion, as evidenced by major celebrations and 
ceremonies, especially those that are affiliated with marriages and births. For instance, the ancient tradition of applying sindoor(red paste) in the parting of a married woman's hair, was adapted by Muslim brides, who haveafshan (gold dust) placed in their partings at the time of their nuptials. The author even describes, and includes illustrations of, ancient and modern nutcrackers and paan-boxes, rangoli(coloured chalk) floor patterns and decorative trays that collectively inform the cultural commonalities of sub-continental traditions. The text is wellwritten, and richly illustrated throughout, and is accompanied by an enjoyable DVD that documents the lives of famous sub-continental women such as the architect, Yasmin Lari, and the lawyer, Asma Jahangir, among others.

At the launching of her book, I asked Naz Ikramullah about her mother's influence over her development as an artist and writer. She responded that one of the most remarkable things about her mother's life was that in spite of being in purdah (strictly veiled) until she was eighteen, she became an active voice for women's empowerment over the course of her illustrious career. In a sense this left her daughters with no choice other than to avidly pursue their respective paths to success. For Ms. Ikramullah, this book represents one of her personal journey's most vivid landmarks.

Nadya Chishty-Mujahid (Institute of Business Administration)

Modern man is threatened by a world created by him. He is face with conversion of mind of naturalism, a dogmatic secularism and an opposition to a belief in the transcendent. He begins to see, however, that the universe is given not as one existing and one perceived but as the unity of subject and object that the barrier between them cannot be said to have been dissolved as the result of recent experience in the physical sciences, since this barrier has never existed.

Erich Fromm, The Heart of Man, p.197-198 